\title{
Re-positioning Wor(I)ds in the Literary Map: Translation as a Token of Mobility
}

Davi Gonçalves

\begin{abstract}
This study is grounded on the hypothesis that the translator operates within a two-way road; thereby, when it goes to the dialogue established between Canada and Brazil the concept of Americanity is bestowed with the responsibility of giving and receiving. Literature might thus help us shape an American, continental utopia. The reflections provided here focus then on my translation of Leacock's novel, whereby the assets and drawbacks of providing my readers with such utopia are considered and elaborated upon. My findings evince that Stephen Leacock's novel is not only Canadian, but from a particular Canadian context permeated by epistemes that make target and source audiences at the same time similar and opposed. Literary meanings are mobile and obscure; a decoy that shows there is no literary essence, but only literary absence. The secret is to decode the silence produced by absence and that is precisely the point of translating.
\end{abstract}

Keywords: Literary translation. Sketches. Leacock. Continentality.

\section{Re-posicionando Palavras e Mundos no Mapa Literário: A Tradução como Sinal de Mobilidade}

Resumo: Este trabalho parte da hipótese de que o tradutor opera em uma via de mão dupla. Assim, no que concerne o diálogo estabelecido entre Canadá e Brasil, o conceito de Americanidade emerge como responsável por informar e receber. A literatura, logo, pode nos ajudar a dar forma a uma utopia de continentalidade americana. As reflexões trazidas aqui focam então na minha tradução do romance de Stephen Leacock, considerando e elaborando acerca das vantagens e desvantagens relativas a proposição de tal utopia. Os resultados nos lembram que meu objeto de análise não é apenas canadense, mas pertencente a um contexto particular canadense permeado por epistemas que ao mesmo tempo aproximam e afastam o público fonte e alvo. Significados literários são móveis e obscuros; uma armadilha promovida pelo fato de que não existe uma essência literária, mas sim uma ausência literária. O segredo é decodificar o silêncio produzido pela ausência - e é esse precisamente o ponto de traduzir.

Palavras-chave: Tradução literária. Esquetes. Leacock. Continentalidade. 
Tudo é decidido pelas palavras: tanto o valor de um poema como o destino de um homem. (KOSZTOLÁNYI, 1996, p. 9)

\section{Introduction: Literature and Americanity as Practices of Survival}

In the contemporaneity, literary criticism has learned to acknowledge the quality and relevance of a huge number of novels, short stories, and poetry written in English, but emerging from countries external to England and the U.S. Among some of the most successful writers who fit in this frame one could mention the Scottish Robert Louis Stevenson, the Irish James Joyce, the Welsh Richard Llewellyn, among many others. In a more contemporary scope, the Canadian Margaret Atwood has been in the international spotlight for quite a while, even with all the difficulties (that she herself recognizes and discusses in several of her texts) found for her to write a literature which is inevitably "North-American" even though it is not produced inside the USA. Atwood (1972) discusses deeply the matter of Canadian literary identity emphasizing, among other things, the importance for one to look for models that escape from the hegemonic pattern imposed by central cultures. Keith (1989) suggests that every region, for being at the same time unique but diverse, develops an idiosyncratic culture and, consequently, a literature with the same characteristics. National identities tend to present themselves in a process of maturation with literary traditions - whose status has already been historically acquired and reaffirmed. Hegemonic culture is thereby not only imposed, but reinforced, aiming at inserting its singular literary shape, initially clearly local, in a universal imagery that is unavailable to marginalised regions.

In what regards the impact of the aforementioned process, specifically in Canada, Keith (1989, p. 17) affirms that "an important insight that can illumine our understanding of what is potentially distinctive about Canadian fiction is that, stated at its simplest, our fictional tradition is much closer to oral origins than its English counterpart". This information is not used by the author for mitigating the intellectual strength of Canadian literature, as if it were "less developed" than other traditions just because it is closer to oral origins; what he defends is 
actually the opposite. Ideological autonomy regards the sovereignty (so often forbidden for those outside the central scopes) of one person or people not only to produce a certain discursive episteme, but to having listeners as eager to listen to such production as they would for more hegemonic ones. Todorov (2007, p. 14) notices that "a particular type of discourse is defined by the rules which it must obey"; and, following such rules, one would again return to those mentioned patterns of universalism problematized by the author. Todorov would demonstrate afterwards how even the literary discourse - which is, supposedly, borderless - is frequently under the restrains and perimeters imposed by certain rules (not only concerning their conception but also when one ponders upon its spreading thereafter). The translator, moving between cultures without the need for belonging exclusively to any of them, operates within a two-way road, and, in this case, at such road the concept of Americanity is bestowed with the responsibility of giving and receiving. Of allowing self and other to merge without one having to assimilate the other - the result of which shall not be conflict, but identification.

Bhabha (1994, p. 43) avers that "[t]he question of identification is never the affirmation of a pre-given identity, never a self-fulfilling prophecy - it is always the production of an image of identity and the transformation of the subject in assuming that image". That who wishes to affirm a pre-given identity enters the dialogue without the necessary tools to make it succeed; there is no prophecy to be fulfilled, the process could be better described as an interchange of images - the interactive activity of transforming and allowing to be transformed. "The demand of identification - that is, to be for an Other - entails the representation of the subject in the differentiating order of otherness. Identification is always the return of an image of identity that bears the mark of splitting the Other place from which it comes" (p. 45). In contemporaneity, it seems clear, one is indeed compelled to ask for differentiating orders of otherness as to stop assuming the universal narrative to the detriment of the local one. The endeavour of going and returning sounds compulsory if an American continentality is to be achieved; the translation of Americanity therefore is articulated at the same time as one is guided to (re)open one's eyes not only for looking at the other Americas less predictably, but, and perhaps especially, for looking at oneself anew. In the American postmodern condition, furthermore, it is high time subjects started to reclaim their right to have their significations understood, not incorporated within the 
hegemonic narrative. As a matter of fact, "the time for assimilating minorities to holistic and organic notions of cultural value has dramatically passed" (p. 174).

Bearing in mind that it is now time for the deviating meanings to surmount universal preconceptions and holistic enterprises, Americanity has many contributions for Bhabha's critique inasmuch as the idea of a shared American identity is articulated from the maxim of reconstruction, through the retextualisation of both margin and centre as less antagonistic as they have been seen so far. As to assist such quite ambitious endeavour, literature seems of paramount importance for its cultural inputs might go way beyond any political and social innocuous diplomatic statement on American (inter)continentality. Culture, nonetheless, is only effective if it is given the chance to provoke - to make both self and other uneasy throughout their subjective experience. If culture is unable to cause distress, then the effectiveness of the cultural dialogue through literary translation sounds, to say the least, rather questionable. As a matter of fact, it is pivotal to keep in view that the history of subalternity and of its conquered presence within the contemporary cultural arena is one whereby literature has been working as to aid the materialisation of the American continentality kind of utopia to be seen in a less blasé fashion. Cultural uneasiness, in this sense, is needed even though the ultimate aim of the dialogue is interactive easiness; one needs to go through the duress of cultural repositioning for such positioning to occur smoothly but through ideological awareness - if no duress takes place there is no ideological awareness, only alienation. Through literature, therefore, "culture becomes as much an uncomfortable, disturbing practice of survival and supplementarity between art and politics, past and present, the public and the private - as its resplendent being is a moment of pleasure, enlightenment or liberation" (BHABHA, 1994, p. 175).

The cultural bridge designed by Americanity gives literary translation the chance to liberate the subjects through pleasure rather than through obligation. Commitment thus occurs in a natural fashion, not because it is compulsory but because literature, by definition, requires it to happen. Literature, like language, shapes and is shaped by the subject who employs it, in a dual movement - one wherein dialogue is not an option, it is a prerequisite. In this sense it is imperative not to underestimate or miscalculate each specific configuration of Americanity, Américanité, Americanidad, and Americanidade as concepts that translate the singularity of a 
GONÇALVES, Davi. Re-positioning Wor(l)ds in the literary map.

given context - as local versions of American continentality rather than a universal version of it. This sounds important because each context, language, literature provides subjects with an idiosyncratic array of tools to construct and be constructed in a given space and time. As Schleiermacher (2001) has affirmed more than two centuries ago, people are subjected to the power of the language they speak; their thinking and themselves are a product of their contextual reference. The configuration of subjects' concepts is only possible because there had been another concept beforehand - nothing is purely original; on the other hand, each person is nonetheless given the means to think spontaneously within the frontiers of his/her contextual milieu. ${ }^{1}$ To put it bluntly, what Schleiermacher seems to mean here is that language would not really define us, but only help us be defined. Nevertheless, if the subject can operate spontaneously only inside the contextual parameters encompassing his/her spatial and temporal configuration, wouldn't the cultural experience of Americanity provide an opportunity for such context to be broadened? Well, it seems it all depends on the manner whereby translation occurs.

\section{Discussion: Reimagining Communities in my Translation of Leacock's Novel}

"Sunshine Sketches of a Little Town compiles sketches whose central character is the town of Mariposa - Orillia, Ontario, where Leacock spent his summers and where some citizens were outraged by his unflattering comic portrait" (LYNCH, 1984, p. 274). Mariposa might be deemed a fictional-but-real village, since it is described by Stephen Leacock in his Sunshine Sketches as having clear autobiographic characteristics and being based on the Canadian city Orillia and on the inhabitants of the Canadian township Mariposa. Mariposa shall be here considered the main character of the book going, therefore, way beyond the sole geographic configuration of the narrative setting. It is worth mentioning anew, nevertheless, that it is

\footnotetext{
1 "Jeder Mensch ist auf der einen Seite in der Gewalt der Sprache, die er redet; er und sein ganzes Denken ist ein Erzeugniß derselben. Er kann nichts mit völliger Bestimmtheit denken, was außerhalb der Grenzen derselben läge; die Gestalt seiner Begriffe, die Art und die Grenzen ihrer Verknüpfbarkeit ist ihm vorgezeichnet durch die Sprache, in der er geboren und erzogen ist, Verstand und Fantasie sind durch sie gebunden. Auf der andern Seite aber bildet jeder freidenkende geistig selbstthätige Mensch auch seinerseits die Sprache"
} 
Leacock's Mariposa that shall be taken as the main character of the book, and not the "real" city of Orillia. The town in the sketches is one whose features are set forth through the eyes and interferences of Leacock - which shall be even further modulated by my own discourse as a translator. In this sense I am by no means intending to move into an inner quality of Mariposa being "similar to Orillia"; I just want to keep close to the fictional setting for this is a setting which I understand as being fruitful precisely because it belongs to the fantastic. In this sense one good example of the unreliability of Leacock's narrator's comments taking place is the fact that the town of Mariposa "is introduced by the narrator as a busy, hustling, thriving town and a perfect hive of activity [...]. This evaluation, however, cannot be further from the truth as it is evident from the narrator's description of Mariposa's activity" (KLOUDA, 2010, p. 19). This ambivalence happens for Leacock is, actually, criticising this idealised view on "the city". In this sense, one should not read Leacock's novel without being careful for the basic characteristic of the ironist is that he is usually saying the complete opposite that an excerpt like that seems to be proposing.

My translation of Sunshine Sketches of a Little Town does not aim therefore to erase the local colour that permeates the sketches. On the contrary, what I want is for the Brazilian reader to remember that such book is not only Canadian, but specifically from a small Canadian village, of 100 years ago, full of people with distinct values, practices, and ideologies but who are, at the same time, pretty much like contemporary Brazilian readers. Ultimately, my translation does not aim at homogenising the characters' identities, but to empowering their hybridity as to manifest how such hybridity reaches Canadians and Brazilians with strength and effectiveness. The hope behind my choices in this translation is thus not symptomatic of a supposed will to turn anything concrete into something more palpable; but, on the contrary, only of my attempt at enhancing the liquescent character of Leacock's narrative through a more literary than technical approach towards it. Identities, as obvious as this might seem, are not disposable, capable of being updated by eternal means. The interaction is always there, stronger or weaker, to convince us that such realms cannot and shall never be divided, since "[t]he concept of a single, exclusive, and unchanging ethnic or cultural or other identity is a dangerous piece of brainwashing. Human mental identities are not like shoes, of which we can only wear 
one pair at a time. We are all multi-dimensional beings" (HOBSBAWN, 1996, p. 1067). To embrace one's future through the abandonment of one's past would be to believe that indeed the concept of an unchanging identity is something possible of being achieved and/or fostered. If one's identity is nonetheless really "not like shoes", such worry is a trifling one, whose tenets are, undoubtedly, easily questioned, notwithstanding how powerful they might still be (regardless of how old the novel is) in our very XXI century.

Apropos, in Leacock's narrative, there is a character who often embodies such progressive linearity, the self-centred Mr. Smith. He is the one character that comes to Mariposa from "the city" as to stand for a symbolic trigger for Mariposan insertion in the future of Canada, a future whose credibility has been granted by other nation's epistemes whose ideological foundations have supposedly already been tested and proven considerably beneficial. When he decides to build and manage a café, this character - whose main attribute is his supposed ability to put the previously old-fashioned Mariposa in the global map of Canadian future - is asked if, in case anything went wrong, he would give up on keeping with the café or tried to set forth any modernistic plan in Mariposa. Smith's response is nonetheless as clear-cut as it could be. If the activity he proposes resulted in any sufficient fruits, he would already have convinced himself (and others) that the local colour is good enough for him to paint Mariposan future. “'Boys', said Mr. Smith, 'I don't rightly know. If I have to quit, the next move is to the city. But I don't reckon that I will have to quit. I've got an idée that I think is good every time"” (LEACOCK, 1992, p. 13). ${ }^{2}$ Besides this discussion between local and universal, having Mariposa as a representative of the former and the city as a representative of the latter, another curious aspect towards which one should have his attention directed in this excerpt concerns the usage of the word "idée". When Smith says he has got an "idée" that he believes might serve him well every time, he applies not the English word "idea" but the French "idée". Such moments shall not be overlooked during the translation process, nor shall they be

\footnotetext{
2 "Rapazes", disse Smith, "agora já não sei ao certo. Se eu tiver que desistir, o próximo passo seria rumo à cidade. Mas eu não creio que seja o caso, eu tenho uma idée que acredito ser boa em qualquer momento." (Every translation of Leacock's novel is part of my work in progress).
} 
adapted or domesticated into Portuguese - which would result in the expunging of its linguistic and ideological contextual inner references.

This is not the only moment when French language or French history is brought by Leacock - which makes us knowledgeable about the fact that, concerning Canada, both the Anglophone and Francophone contexts are of paramount importance and relevance. These are two realms that have, within the country, been the reason for contacts and conflicts that endure up to the present moment. When Leacock reminds us that none of these traditions can be thought about as isolated in the political borders artificially created to divide them, he seems to be willing to show us how such contact also had as an inevitable consequence a nation where languages, traditions, and beliefs interact and converge into a hybrid culture. The word "idée" can actually already be found in most English language dictionaries, as a borrowing from French. Curiously, therefore, one could conclude that, sometimes, language emerges, per se, as a channel for reflection upon social and political issues that are generally taken for granted. That is, if the national ideal can only reaffirm itself through erasing or ignoring the potential for identities to merge rather than to move through opposing directions, somehow language is, in most of the times, positioned on a step further when compared to politics. But how can such a problematic illusion that the artificial boundaries politically created are indeed capable of thriving in a borderless society like ours? The moment when Leacock's novel was written marks the advent of globalisation perhaps in its most intense version and, even though such issue was only going to enhance thenceforth, the national identity is still doomed to be regarded as single, concrete, and devoid of any interferences from the "outside". In the words of Anderson (1996, p. 123) this is so because "since the end of the eighteenth century nationalism has undergone a process of modulation and adaptation, according to different eras, political regimes, economies and social structures; the 'imagined community' has, as a result, spread out to every conceivable contemporary society".

Like religion, then, the only manner for the national ideal to go through its maintenance and for it to still be credited from the XVIII century up to the XXI one was to allow itself to undergo a process of modulation and adaptation. Every political, financial, or social transformation has resulted in a new version of the national ideal, but generally with the same 
GONÇALVES, Davi. Re-positioning Wor(l)ds in the literary map.

superiority vs. inferiority premise, according to different eras. In the specific case of Leacock's characters, this "different era" wherein Mariposans are being convinced they need to fit in is, indeed, not one where the fake national surface shall be disclosed, but when where it might be provided another layer to cover its impossibility in a moment that requires new approaches to the idea of what it means to be from a certain nation. It is interesting to think about this "modulation and adaptation" mentioned by Anderson that was taking place since the end of the XVIII century when one pays attention to the narrator's description of Jeff's barber shop and its "false front". The false front of the barbershop might indeed be nothing but an architectural detail, but it might also be read as a metaphor for the superficiality of its giving such an "imposing" impression of a very simple place. So, as the narrator would later admit, it is in order to keep up with the pretentious and artificial character of modern life that the barbershop has that architecture which was actually much common in Mariposa. The painting of the post in front of it is also not there only by chance; painted in red, white, and blue colours it is also a symbolic reminder of national identity, like a flag or national symbols, so recurring in the culture of any nation and so useless to represent any of its inhabitants' values.

\begin{abstract}
The barber shop, you will remember, stands across the street from Smith's Hotel, and stares at it face to face. It is one of those wooden structures - I don't know whether you know them - with a false front that sticks up above its real height and gives it an air at once rectangular and imposing. It is a form of architecture much used in Mariposa and understood to be in keeping with the pretentious and artificial character of modern business. There is a red, white and blue post in front of the shop and the shop itself has a large square window out of proportion to its little flat face. (LEACOCK, 1992, p. 27) ${ }^{3}$
\end{abstract}

Bearing in mind that the supposed dichotomy Smith vs. Mariposans is one of those ambivalences that I am eager to problematise in my study, this excerpt reminds us of something else. "Sunshine Sketches at once partakes of, 'explodes' the conventions of, and is the artistic

\footnotetext{
${ }^{3}$ A barbearia, acho que você vai lembrar, fica na rua do Smith Hotel, na verdade bem na frente dele. É uma daquelas estruturas de madeira - eu não sei se você as conhece - com uma frente falsa que fica muito acima da sua altura verdadeira e dá-lhe um ar ao mesmo tempo retangular e imponente. É uma forma arquitetônica muito usada em Mariposa e entendida como estando em sintonia com o caráter pretensioso e artificial dos negócios modernos. Há um poste vermelho, branco e azul na frente da loja, e a própria loja tem também uma grande janela quadrada totalmente desproporcional com a parede simples na qual se encontra.
} 
fulfillment of the local-colour literary tradition of the turn of the century" (KLOUDA, 2010, p. 17). It seems the reason for the architecture of Jeff's barbershop, for the post in front of it, and for the national anthem being sung while the boat sinks can be thought of as an attempt at blinding those whose local colours are indeed being modeled. One must not understand what the national identity is about simply because "[t]he one persistent feature of this style of nationalism was, and is, that it is official - i.e. something emanating from the state, and serving the interests of the state first and foremost" (ANDERSON, 1996, p. 123). It is thus the privileging of the state that mark this one persistent feature of nationalism; our national pride has been constructed and reinforced in order for us not to fight for our freedom or justice, but for the freedom and justice of something we are sure that represents us. But does it really represent anyone other than hegemonic marketing and political enterprises? I would never say so, anything that endorses the illusion of our imagined national community can only do that through the marginalisation of anything that deviates from the supposed national pattern; such pattern is nonetheless only a construction that deserves to be rethought and, ultimately, discredited. If we are indeed to adapt different eras and social structures, why cannot we adapt to the era of information, the era of coming up with the inner flaws of the national utopia as to put its pillars into question and wipe out its influence on us?

It is not the barbershop, though, that most strongly embodies such discussion on Mariposan development through the illusion of national reaffirmation; it is when Mr. Smith decides to open a café that it gains more palpability. Readers remember that, by the way, Jeff's barbershop was located in front of Smith's hotel, that, up to that moment, had indeed been nothing but a hotel for those coming from "the city". Later on, nonetheless, the enterprising heart beating in Smith's chest would convince him that it would also be a nice idea to open a café in his hotel, and, in order to attract the best customers he could have within it, there was only one possible path. The plan of opening the café, which was ready in two weeks, entailed so many changes in the hotel whose owner was also Smith that, in the narrator's view, its construction resulted in many more transformations. This can be read as a metaphor to the fact that the modernising changes brought forward by the developmentalist process of universalising the local inevitably results in the alteration of the main structure of any system previous to the 
advent of such process. That is, amendments are brought to heal the body, but, in the end, the body ends up becoming another one; the medicine for helping, improving, enhancing something would thus work as a synonym to changing the whole structure of this very same thing. The other gadgets mentioned by the narrator are also rather meaningful, such as the box of hanging plants to draw customers' attention to the café and the awnings that emerge out of nothing, serving as a representation of the national identity. This reminds customers that that café was a place where their nation was respected and admired; true or false, such statement could easily attract people who were proud of being Canadian Mariposans.

Within two more weeks the plan was in operation. Not only was the caff built but the very hotel was transformed. Awnings had broken out in a red and white cloud upon its face, its every window carried a box of hanging plants, and above in glory floated the Union Jack. The very stationery was changed. (LEACOCK, 1992, p. 20) ${ }^{4}$

Concerning the last gadget and symbolic reference to national identity, I faced a translation problem that it is perhaps worth mentioning. When the narrator says that above the hanging plants "in glory floated the Union Jack" how could I translate such seemingly simple sentence into Portuguese? In terms of concrete meaning the problem could be easily solved, since Union Jack can be simply called "Bandeira do Reino Unido"; Leacock, nevertheless, has not chosen to write UK flag, but Union Jack, whose ideological roots take his readers to a broader meaning-making system than it would if we stuck only with the idea of the flag. The Union Jack is indeed the flag of the United Kingdom, also known by law in Canada as the Royal Union Flag, which, when the novel was written, was still used as to represent the Canadian nation - and this until 1964, when the Maple Leaf Flag was chosen to replace it as the national flag. After no longer being capable of representing the Canadian nation, the flag started to be used only when Canadian allegiance to the British crown needed to be symbolised. Today one could affirm that simply calling it the UK flag would be simpler, more common, and more

\footnotetext{
${ }^{4}$ Dentro de duas semanas o plano já entrava em operação. O café não foi apenas construído dentro do hotel, na verdade o próprio hotel foi transformado. Toldos emergiram como uma nuvem branca e vermelha; e cada janela passou a ser preenchida com vasos de flores penduradas, e, por cima delas, flutuava em glória a Union Jack. Até o que não tinha como mudar mudou.
} 
accurate. However, my foreignising decision to translate the sentence into "flutuava em glória a Union Jack" rather than adapting it to "flutuava em glória a bandeira britânica" is due to the fact that "Union Jack" was a common term to name the flag when the British navy was conquering most of its colonies. At that time British soldiers were called Jack Staff, this is probably why the flag's nickname Union Jack was adopted. It seems to be more plausible to keep close to the colonial and neocolonial linguistic potential of the term rather than transforming it into something else as to promote easier comprehension to the detriment of the inevitable ideological richness of calling it Union Jack. There is a clear association of the town to the idea of colonies being conquered and institutionalised by Britain, as the little Mariposa was being in the eyes of the narrator.

But why is a flag so important for my analysis and translation? Well, because, like a map, it is a very symbolic representative of the spatial and temporal boundaries of national identity and, consequently, of the local vs. universal problematic binarism. Nevertheless, how effective can a map be to represent a certain geographical structure? Not much, as Anderson suggests, since, in his view, "[i]n terms of most communication theories and common sense, a map is a scientific abstraction of reality". Even though to common sense this map (like the flag) is successful in standing for something that transcends its concrete dimensioning,

[a] map merely represents something which already exists objectively 'there'. In the history I have described, this relationship was reversed. A map anticipated spatial reality, not vice versa; in other words, a map was a model for, rather than a model of, what it purported to represent (ANDERSON, 1996, p. 134).

Curiously, it seems, notwithstanding the fact that the map emerges as an opportunity to represent the supposed reality, what happens in local realms such as Mariposa, which are welcoming the advent of developmentalist processes to adapting the financial, social, and political practices, is that this whole relationship is indeed reversed. It is not Mariposa coming first and the map accompanying it, but the opposite, it is first convinced to be something and thus to try to change those things that are, supposedly, a hindrance for its survival. One of these changes (already addressed beforehand) concerns Mariposan will to have its social relations taking place in a similar fashion when compared to those in the city. Interestingly, the narrator 
does not seem to be sure about the fact that he wants the town to follow such pattern; like already mentioned, this is present in his discourse, even though sometimes the opposite also takes place.

The reason why the narrator is bound to keep looking for images which he can never really see but only imagine is simple: such images do not exist; they are just an invention with no evidence of applicability based on his admiration for what he would like Mariposa to be. The argument is mistaken but it is stuck in every subject's minds: the pillars of capitalist enterprises require us to see everything that has supposedly to do with the past (those things that have to do with the specific, the isolated, the local) as insignificant. We learn also to see everything that has supposedly to do with the future (those things that have to do with the global, the globalised, the universal) as of paramount importance. As a matter of fact, "more profoundly and problematically, they [hegemonic narratives] required time to accommodate the schemes of a one-way history: progress, development, modernity (and their negative mirror images: stagnation, underdevelopment, tradition)" (FABIAN, 1983, p. 144). It is high time these schemes of a one-way history were put into question. Those looking for solutions to promote a better understanding between different contexts - which, different from what we have been convinced, are always relevant, no matter how temporally or spatially separated from one's context they might be - can no longer accept the ideology of progress and modernity as the oracle of global issues. Such ideology has been giving us consecutive attestations of how incompetent it is for making us less ignorant about the self and the other, since its goal has been actually to do the opposite. In fact, Leacock's novel and my translation are a material attempt at advocating that it is their negative mirror images - those values emerging from places which, like Mariposa, are generally pinpointed as representing stagnation, underdevelopment, tradition - which might ultimately provide what hegemonic interests have been concealing. As literature and translation recurrently (like in Leacock's case) demonstrate, it is by understanding both self and other as local that they may finally be brought into dialogue. To believe in the tale of universalism is thereby not a first step onto the surfacing of other stories, but the very last step onto allowing hegemonic stories to repress marginal ones. 


\section{Final Remarks: Translation as Analogous to the Rewriting of a Draft}

Passages and transitions are, as Cronin (2003, p. 29) sees them, the natural outcome of altering "our relationship to the sum total of durational elements" - that is, to understand that we do not deal daily with a past versus future binarism, but with the restructuring of one present into another one. This temporal conundrum makes it hard to place Canadian past - as represented in Leacock's novel - and Brazilian future - as the condition wherein my version of it is inevitably inserted - in the separate boxes where we have been taught they would naturally belong to. The discussion here is inherent both to the literary realm and to the realm of literary translation. Nevertheless, even though such discussions concerning translation and its impact on temporal and spatial spheres might be regarded considerably recent, this issue is far from operating likewise. The process of literary translation depends on a sensation of simultaneityalong-time. Given that one of the ways whereby we might connect with other languages and cultures is through translation, "commitment to appropriate, culturally sensitive models of translation would appear to be central to any concept of global citizenship in the twenty-first century" (CRONIN, 2003, p. 30). If one believes there is nothing else that deserves to be experienced, translation becomes useless - hence the need for such commitment to Cronin's models of translation. Indeed, in the XXI century, the particular claims of singular locations have proven to be highly difficult to be noticed and heard by the cosmopolitan subject. The hegemonic idea of global citizenship is ultimately not about promoting the dialogue between those whose traces of difference mark them as separate, but about uttering and reinforcing only one single version of supposed facts.

That is to say we are not living a moment marked by the power of the dialogue, we are living the absolutism of global monologue. Literature and literary translation could therefore surface as effective means for providing us with less predictable views on our traces of differences. Literary translation are then a reminder that what makes us different, in the end, is what - paradoxically - also makes us aware of our similarities. "The argument against translatability is [...] often no more than an argument based on local, temporary myopia" (STEINER, 1975, p. 274). It would be thus the lack of capacity to look around the obstacle that, 
for so many subjects, seems to make the translatable untranslatable. The greatest argument against translatability, by the way, which is the fact that no word has any complete synonym in any language (therefore no term applied in one context shall be capable of doing the same in another) is inherently problematic and can easily be debunked when it is seen as a hindrance for translations to be promoted. This is so for the concrete substances of signs do not exist and they have never did. Language, communication and, consequently, literature are all instances that breathe subjectivity - texts survive because their meanings are immune to solid borders. I propose my translation thus conscious that, in terms of textual substance, the raw material is "the same". The draft Leacock has written is one that is - and shall probably always be-humorous. Translating it invites one to reflect upon how to relocate those literary evidences that would not, to the translator's judgment, cause laughter any longer, and to boost those evidences that are amenable to doing so - regardless of what they meant in the original work, which we shall never be really sure about. When jokes articulated in the original might happen not to make sense in the translation, or at least to be less likely to cause laughter, translators are, through creative infidelity, summoned by the text to shape new possibilities for humour to emerge.

Thereby the new text is liable to be filled in with jokes that might not have been there at the beginning; and the discursive humour of the original text keeps flowing through another originality, through the channels of communication opened up by the translation. The comic, it seems to be clear now, is collective but not universal - it operates effectively because it is inserted in a given context, at a certain time, which requires translation to operate through some sort of temporal compression. All these features of this deep temporal compression that the narrator's long-range analogies and allegorical comments entail are apropos an opportunity for one to disclose how time and space might be less limited than it is generally assumed. To imagine that - because they are temporally and geographically distant - there is no possibility of dialogue between source and target contexts would be to discredit this all-embracing atmosphere of endless contact that cosmopolitan thinking identifies among the most (seemingly) separated subjects. This is so for we have never existed (and shall never exist) as subjects without another "other" to remind us of who we are, to remind us of what we might 
become. The past, like the other, never dies, it never ceases to exist, it never ceases to be relevant: past, present, and future - regardless of the mistaken manner we have been normatively convinced to isolate temporal configurations - are thus not instances that emerge through replacements, they are instances that emerge through an eternal and cyclical communication..$^{5}$ Literary meanings are mobile; they are transformed and repositioned through a process of invisible transmutation - one that evinces how there is no literary essence, but rather a literary absence (we just need to learn how to decode the silences produced by this absence). Translation, in the end, proves to be not the symptom of an endeavor to resurrect the deceased; it is, on the contrary, the evidence that nothing has died in the first place.

\section{References}

ANDERSON, Benedict. Imagined communities: reflections on the origin and Spread of Nationalism. London: New Left Books, 1996.

ATWOOD, Margaret. Survival: a thematic guide to canadian literature. Toronto: Anansi, 1972.

BHABHA, Homi. The location of culture. London: Routledge, 1994.

CRONIN, Michael. Translation and new cosmopolitanism. In: TRANSLATION and identity. London: Routledge, 2003.

FABIAN, Johannes. Time and the other: how anthropology makes its object. USA: Columbia University Press, 1983.

HOBSBAWM, Eric. Language, culture, and national identity. Social Research, New York, v. 63, n. 4, p. 1065-1080, 1996.

KEITH, William. A sense of style: studies in the art of fiction in english-speaking Canada. Toronto: University of Toronto Press, 1989.

KLOUDA, Peter. Sentimentalism in O. Henry and Stephen Leacock. Czech Republic: Masaryk University Press, 2010.

LEACOCK, Stephen. Sunshine sketches of a little town. Toronto: Bell \& Cockburn, 1992.

\footnotetext{
${ }^{5}$ See Fabian (1983)
} 
GONÇALVES, Davi. Re-positioning Wor(l)ds in the literary map.

LYNCH, Gerald. Sunshine Sketches: Mariposa vs. Mr. Smith. Studies in Canadian Literature, Ontario, v. 9, n. 2, 1984.

SCHLEIERMACHER, Friedrich. Sobre os diferentes métodos de tradução. 1813. In: HEIDERMANN, W. (Org.). Clássicos da teoria da tradução: antologia bilíngue (AlemãoPortuguês). Tradução Margarethe von Mühlen. Florianópolis: UFSC, 2001.

STEINER, George. The Claims of Theory. In: AFTER BABEL: aspects of language and translation. London: Oxford University Press, 1975. p. 236-295.

TODOROV, Tzvetan. The notion of literature. New Literary History, Baltimore, v. 38, n. 1, p. 1-12, 2007.

Davi Gonçalves - Universidade Federal de Santa Catarina |
$\begin{aligned} & \text { Florianópolis | Santa } \\ & \text { goncalves.davi@hotmail.com }\end{aligned}$

Artigo recebido em abril de 2016 e aprovado em junho de 2016 